\title{
STRATEGI PENINGKATAN PERTUMBUHAN EKONOMI MELALUI INVESTASI INFRASTRUKTUR JALAN DAN JEMBATAN DI PROVINSI BANTEN
}

\author{
Strategies for Increasing Economic Growth through Road and Bridge Infrastructure \\ Investment in Banten Province
}

\author{
Fitria Diah Hastuti', Ma'mun Sarma², Manuwoto² \\ 1 Staf Direktorat Jenderal Bina Konstruksi, Kementerian Pekerjaan Umum dan Perumahan Rakyat. Email: \\ fitria.diahhastuti@gmail.com \\ 2 Staff Pengajar Departemen Manajemen. Fakultas Ekonomi dan Manajemen IPB Email : \\ mamun_sarma@yahoo.com, \\ Staff Pengajar Sekolah Pascasarjana IPB Email: mmnuwoto@gmail.com
}

\begin{abstract}
Road and bridge infrastructure investment can increase economic growth. The purposes of this study are to analyze the budget for road infrastructure development in Banten Province, analyze the effectiveness of road and bridge infrastructure investment for economic growth in Banten Province and formulate effective strategies to improve economic growth through investments in road infrastructure in Banten Province. The data was analyzed using descriptive analysis, regression, and SWOT analysis.The descriptive analysis explained that growth of budget and its realization. Based on regression analysis, road and bridge infrastructure investments are significanly influence for the economic growth. Strategies for increasing economic growth through road and bridge infrastructure investment in the Province of Banten is synergy between government, private sector and public to improved road infrastructure by using corporate social responsibility towards the construction of roads and bridges for the industries related to the level of damage, liaison in subsections in the Department of Highways and Spatial Planning is responsible for the activities that involve interaction with the public related to road and bridge infrastructure investments. meeting regularly to discuss and resolve issues that occur between institutions.Keywords: Indramayu, Competitiveness, Investment Increasing Strategy
\end{abstract}

Keywords : Infrastructure, Economic Growth, Regression and SWOT analysis

\begin{abstract}
ABSTRAK
Investasi infrastruktur jalan dan jembatan dapat meningkatkan produktivitas dan pertumbuhan ekonomi. Penelitian ini bertujuan untuk menganalisis anggaran infrastruktur jalan dan jembatan di Provinsi Banten, menganalisis efektifitas investasi infrastruktur jalan dan jembatan dikaitkan dengan pertumbuhan ekonomi dan menyusun strategi di bidang infrastruktur jalan dan jembatan yang efektif meningkatkan pertumbuhan ekonomi. Analisis data dilakukan dengan metode analisis deskriptif, analisis regresi, dan analisis SWOT. Analisis deskriptif menjelaskan pertumbuhan anggaran dan realisasi jalan dan jembatan di Provinsi Banten. Berdasarkan hasil regresi, variabel jalan dan jembatan berpengaruh signifikan kepada pertumbuhan ekonomi. Strategi untuk meningkatkan pertumbuhan ekonomi melalui investasi infrastruktur jalan dan jembatan di Provinsi Banten adalah melakukan sinergi stakeholder pemerintah, swasta dan masyarakat melalui program Corporate Sosial Responsibility (CSR) yang ditujukan pada pembangunan jalan dan jembatan bagi industri yang terkait dengan tingkat kerusakan jalan, difungsikannya secara intensif Subbagian humas di Dinas Bina Marga dan Tata Ruang (BMTR) yang bertanggungjawab terhadap berbagai kegiatan investasi infrastruktur jalan dan jembatan yang melibatkan masyarakat dan rapat secara rutin untuk membahas dan menyelesaikan permasalahan yang terjadi antar instansi. Kata kunci : Infrastruktur, Pertumbuhan Ekonomi, Regresi, dan Analisis SWOT
\end{abstract}

\section{PENDAHULUAN}

\section{Latar Belakang}

Infrastruktur merupakan komponen yang penting dalam menunjang pembangunan suatu negara. Hal ini sesuai dengan arahan Presiden Joko Widodo yang menekankan bahwa sektor infrastruktur menjadi salah satu prioritas pemerintahan dalam mendorong laju 
pertumbuhan ekonomi nasional. Menurut data Kementerian Perencanaan Pembangunan Negara/Badan Perencanaan Pembangunan Nasional (PPN/Bapenas), pemerintah dalam lima tahun mendatang (2015-2019) mencanangkan pembangunan jalan tol sepanjang $1.000 \mathrm{~km}$, jalan baru $2.650 \mathrm{~km}$, dan pemeliharaan jalan $46.770 \mathrm{~km}$.

Pembangunan infrastruktur di suatu daerah memerlukan investasi infrastruktur oleh pemerintah daerah tersebut. Hal ini dapat diwujudkan melalui anggaran yang tertuang dalam Anggaran Pendapatan dan Belanja Daerah (APBD). Valeriani (2011) mengungkapkan bahwa fasilitas Infrastruktur fisik berkontribusi kepada pertumbuhan ekonomi dengan cara mengurangi biaya transaksi dan menciptakan banyaknya investasi, lapangan kerja, hasil (output), pendapatan dan pertumbuhan ekonomi. Janeski et al (2014) mengungkapkan pemerintah perlu melakukan program yang efektif dengan pembangunan infrastruktur publik yang tinggi pada saat slow down economic.

Putri (2015) peranan pengeluaran pemerintah baik yang dibiayai melalui

APBD, khususnya pengeluaran untuk human capital dan infrastruktur fisik, dapat mempercepat pertumbuhan ekonomi. Hal tersebut sangat tergantung pada sejauh mana produktifitas pengeluaran pemerintah dapat mempengaruhi total output yaitu melalui penyediaan infrastruktur dan barang-barang publik.

Pertumbuhan ekonomi tersebut merupakan salah satu indikator keberhasilan pembangunan. Pertumbuhan ekonomi adalah proses kenaikan output perkapita yang terus menerus dalam jangka panjang. Dengan demikian makin tingginya pertumbuhan ekonomi biasanya makin tinggi pula kesejahteraan masyarakat, meskipun terdapat indikator yang lain yaitu distribusi pendapatan (Sukirno, 2013).

Pertumbuhan ekonomi suatu negara merupakan rata-rata dari pertumbuhan ekonomi provinsi-provinsi di negara tersebut. Salah satu Provinsi di Indonesia yang dinilai dapat memberikan pengaruh adalah Provinsi Banten. Pengaruh Provinsi Banten termasuk yang diperhitungkan karena Provinsi Banten merupakan bagian dari wilayah Jawa-Bali yang pengembangannya harus dilakukan dengan keterpaduan program antar provinsi untuk mendukung alokasi sumberdaya yang efisien dan pertumbuhan yang lebih seimbang.

Wilayah Jawa-Bali sendiri memiliki karakteristik yang khas dengan posisinya sebagai pusat kegiatan ekonomi dan pariwisata Indonesia dan lokasi pusat pemerintahan (Bappenas, 2015). Provinsi Banten berada pada urutan ketiga terendah diantara provinsi-provinsi di Wilayah JawaBali dari segi pertumbuhan ekonomi pada tahun 2013. Urutan pertumbuhan ekonomi

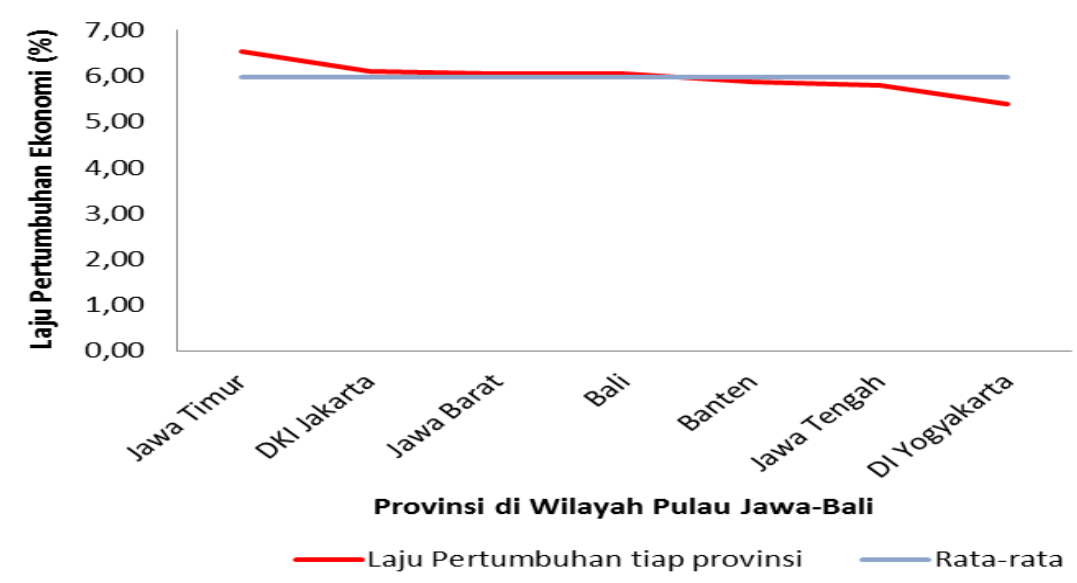

Sumber: Badan Pusat Statistik (BPS), 2015

Gambar 1. Laju Pertumbuhan Provinsi-Provinsi di Wilayah Pulau Jawa-Bali Tahun 2013 atas Dasar

PDRB Harga Konstan Tahun 2000 
mulai dari yang terbesar hingga terkecil di Pulau Jawa adalah Jawa Timur, DKI Jakarta, Jawa Barat, Banten, Jawa Tengah, dan DKI Yogyakarta. Rata-rata pertumbuhan ekonomi di Wilayah Jawa-Bali adalah 5.97\%. Sebagaimana disajikan pada Gambar 1 pertumbuhan ekonomi Provinsi Banten masih berada dibawah rata-rata regional Jawa-Bali.

Komitmen Provinsi Banten untuk meningkatkan pertumbuhan ekonomi demi mewujudkan kemajuan daerahnya diwujudkan dalam visi dan misi yang tertuang dalam Rencana Pembangunan Jangka Menengah Daerah (RPJMD) Provinsi Banten. Adapun rencana pembangunan Provinsi Banten sebagaimana tercantum dalam RPJMD Provinsi Banten Tahun 2012-2017, menyebutkan bahwa salah satu kebijakan umum di bidang pekerjaan umum Provinsi Banten adalah memantapkan kondisi jalan dan menambah panjang jalan guna mendukung pelayanan pergerakan orang, barang, dan jasa (Bappeda Banten, 2012). Jalan merupakan infrastruktur yang sangat dibutuhkan bagi transportasi darat sebagai penghubung satu wilayah dengan wilayah lainnya (Ma'ruf dan Daud, 2014). Berdasarkan Undang-Undang Republik Indonesia Nomor 38 Tahun 2004 jalan provinsi merupakan jalan kolektor dalam sistem jaringan jalan primer yang menghubungkan ibukota provinsi dengan ibukota kabupaten/kota, atau antar ibukota kabupaten/kota, dan jalan strategis provinsi. Perkembangan kuantitas jalan di Provinsi Banten dari tahun ke tahun semakin meningkat. Namun, ada hal yang perlu dicermati terkait kerusakan jalan provinsi, yang semakin lama semakin parah, yang berawal dari tahun 2012 hingga tahun 2014. Penambahan panjang jalan yang rusak semakin lama semakin tinggi. Hal tersebut dapat dilihat pada Tabel 1.

Tabel 1. Kondisi jalan provinsi di Provinsi Banten

\begin{tabular}{ccccc}
\hline & \multicolumn{4}{c}{ Jalan dalam kondisi (dalam km) } \\
\cline { 2 - 5 } Tahun & Baik & Sedang & $\begin{array}{c}\text { Rusak } \\
\text { Ringan }\end{array}$ & $\begin{array}{c}\text { Rusak } \\
\text { Berat }\end{array}$ \\
\hline 2008 & 540 & 110 & 239 & 0 \\
2009 & 327 & 375 & 186 & 0 \\
2010 & 280 & 348 & 143 & 0
\end{tabular}

\begin{tabular}{rrrrr}
2011 & 355 & 254 & 162 & 0 \\
2012 & 429 & 216 & 129 & 79 \\
2013 & 230 & 380 & 174 & 67 \\
2014 & 505 & 194 & 60 & 214 \\
\hline
\end{tabular}

Sumber : BPS, 2015

\section{Perumusan Masalah}

Pertumbuhan ekonomi melalui pembangunan infrastruktur jalan tidak dapat dilepaskan oleh pembangunan infrastruktur jembatan. Jembatan adalah suatu bangunan yang memungkinkan menghubungkan jalan satu dengan jalan lain yang menyilang, sungai/saluran air,

lembah atau menyilang jalan lain yang tidak sama permukaanya (Supriyadi dan Muntohar, 2007). Provinsi Banten memandang pentingnya nilai jembatan dengan mencantumkannya dalam dalam Rencana Pembangunan Jangka Menengah Daerah (RPJMD) Pemerintah Provinsi Banten. Dalam RPJMD tersebut Pemerintah Provinsi Banten berencana mengganti jembatan yang sudah tidak sesuai atau layak serta memperlebar jembatan yang berada di jalan strategis dengan lebar minimal 7 (tujuh) meter. Hal ini mengingat nilai penting jembatan sebagai sarana transportasi mempunyai peranan bagi kelancaran pergerakan lalu lintas barang dan jasa (Bappeda Banten, 2012).

Namun, jembatan saat ini belum diakomodasi secara intensif di Provinsi Banten. Pembangunan jembatan di Provinsi Banten masih minim karena berdasarkan data yang ada terdapat 360 jembatan gantung di wilayah Kabupaten Lebak. Ratusan jembatan tua tersebut dapat mengakibatkan kecelakaan dan kondisi ini sudah dicermati selama tiga tahun terakhir. Mengingat pentingnya jembatan untuk membuka akses masyarakat terhadap perekonomian maka pembangunan jembatan penting untuk dijadikan skala prioritas pemerintah provinsi Banten.

Penelitian Maryaningsih et.al (2014), Sidik (2011) dan Prasetyo dan Firdaus (2009) menyimpulkan bahwa infrastruktur jalan signifikan memberikan pengaruh yang positif terhadap pertumbuhan ekonomi. Perbedaan penelitian saat ini dengan sebelumnya adalah penelitian dilakukan di Provinsi Banten dan 
menggunakan variabel investasi infrastruktur jalan dan jembatan pemerintah provinsi Banten. Penelitian sebelumnya menggunakan metode kuantitatif, sedangkan penelitian di Provinsi Banten ini dilakukan menggabungkan metode kuantitatif melalui analisis regresi dengan metode kualitatif melalui analisis SWOT.

Salah satu cara yang diharapkan dapat memberikan kontribusi nyata pada peningkatan pertumbuhan ekonomi adalah dengan melakukan investasi infrastruktur. Peran investasi infrastruktur jalan dan jembatan yang dilakukan pemerintah Provinsi Banten merupakan hal yang perlu dikaji efektivitasnya. Sesuai dengan prinsip ekonomi, ada opportunity cost yang dikorbankan pemerintah bila melakukan prioritas pembangunan di suatu bidang, maka tentu akan mengorbankan pembangunan di bidang lain. Pertanyaannya adalah "bagaimana gambaran alokasi anggaran pembangunan infratruktur jalan dan jembatan di Provinsi Banten?”. Selain itu, investasi infrastruktur jalan dan jembatan diharapkan dapat menjadi multiplier effect positif bagi pertumbuhan ekonomi di Provinsi Banten. Hal ini menjadi pertanyaan selanjutnya "bagaimana pengaruh investasi infrastruktur jalan dan jembatan terhadap pertumbuhan ekonomi di Provinsi Banten?“. Berdasarkan dua pertanyaan di atas, ada hal yang penting untuk dikaji. Bagaimana output dari realisasi anggaran yang digunakan untuk memberikan hasil optimal terhadap pertumbuhan ekonomi. Untuk itu perlu ada kajian guna mengetahui "strategi apakah yang paling efektif untuk meningkatkan pertumbuhan ekonomi di Provinsi Banten melalui investasi infrastruktur jalan dan jembatan?”

\section{Tujuan Penelitian}

Tujuan utama dari kajian ini adalah merumuskan strategi meningkatkan pertumbuhan ekonomi melalui investasi infrastruktur jalan dan jembatan di Provinsi Banten. Tujuan yang lebih spesifik untuk menjawab tujuan utama tersebut terdiri dari:
1. Menganalisis

anggaran

untuk pembangunan infrastruktur jalan dan jembatan di Provinsi Banten.

2. Menganalisis efektivitas investasi infrastruktur jalan dan jembatan bagi pertumbuhan ekonomi di Provinsi Banten.

3. Merumuskan strategi yang efektif untuk meningkatkan pertumbuhan ekonomi melalui investasi infrastuktur jalan dan jembatan di Provinsi Banten.

\section{METODE PENELITIAN}

\section{Lokasi dan Waktu Penelitian}

Penelitian difokuskan pada Provinsi Banten, provinsi tersebut dipilih karena provinsi ini memiliki prioritas investasi infrastruktur yang tinggi yang dituangkan dalam RPJMD 2012 - 2017 Provinsi Banten.

\section{Jenis dan Sumber Data}

Data yang dipergunakan kajian ini adalah data primer dan data sekunder. Data primer penelitian ini didapatkan melalui wawancara dan kuesioner dengan pihak terkait yang mengetahui investasi infrastruktur jalan dan jembatan di Provinsi Banten. Untuk mengidentifikasi dan menganalisis kondisi faktor-faktor internal dan eksternal serta rumusan strategi yang akan dikembangkan dipilih responden (expert) dari beberapa instansi yang terdiri atas:

1. Kepala Subbagian Perencanaan Evaluasi dan Pelaporan Dinas Bina Marga dan Tata Ruang (BMTR) Provinsi Banten.

2. Kepala Seksi Perencanaan Jalan dan Jembatan Dinas BMTR Provinsi Banten.

3. Kepala Seksi Pembiayaan, Direktorat Bina Investasi Infrastruktur, Direktorat Jenderal Kementerian Pekerjaan Umum dan Perumahan Rakyat.

4. Asisten Teknik Pejabat Pembuat Komitmen Satuan Kerja non Vertikal Perencanan dan Pengawasan Jalan Nasional di Provinsi Banten, 
Direktorat Bina Marga, Kementerian Pekerjaan Umum dan Perumahan Rakyat.

5. Asisten Teknik Pejabat Pembuat Komitmen Satuan Kerja Wilayah I Pembangunan Jalan di Provinsi Banten, Direktorat Bina Marga, Kementerian Pekerjaan Umum dan Perumahan Rakyat.

6. Auditor Madya Perwakilan Badan Pengawas Keuangan dan Pembangunan (BPKP) Provinsi Banten.

7. Pengendali teknis survey pengelolaan infrastruktur pada pemerintah Provinsi Banten, Perwakilan BPKP Provinsi Banten.

8. Staf perencana senior di Badan Perencanaan dan Pembangunan Daerah (Bappeda) Provinsi Banten.

Data sekunder penelitian ini diperoleh melalui dokumen dari berbagai instansi yang memiliki keterkaitan dengan tujuan penelitian yaitu data data pertumbuhan ekonomi, data anggaran dan realisasi keuangan di Dinas BMTR dan data lain yang terkait investasi infrastruktur di Provinsi Banten Adapun instansi yang terkait yaitu BPS, Bappeda Provinsi Banten, Dinas BMTR Provinsi Banten dan Perwakilan BPKP Provinsi Banten.

\section{Metode Analisis}

Metode analisis data pada penelitian ini ada empat cara yaitu sebagai berikut:

\section{Analisis deskriptif}

Metode penelitian dengan cara mengumpulkan data-data yang sebenarnya kemudian disusun, diolah dan dianalisis untuk dapat memberikan gambaran mengenai masalah yang ada (Sugiyono, 2008). Analisis deskripsi digunakan untuk menggambarkan struktur anggaran dan realisasai jalan dan jembatan di Provinsi Banten.

\section{Analisis regresi (regresi linier \\ berganda)}

Analisis regresi digunakan untuk mengetahui pengaruh investasi infrastruktur jalan dan jembatan dengan pertumbuhan ekonomi di Provinsi Banten. Menurut
Gujarati (1997) model estimasi untuk regresi linear berganda adalah metode asumsi klasik. Untuk mengetahui asumsi klasik terpenuhi maka dilakukan pengujian asumsi model regresi meliputi uji multikoleniaritas, uji heterokedastisitas, uji autokorelasi dan uji normalitas. Ketepatan fungsi regresi dalam menaksir nilai aktual dapat diukur dari goodness of fit.

Secara statistik dapat diukur dari nilai koefisien determinasi, nilai statistik $F$ dan nilai statistik t. Adapun asumsi yang digunakan adalah tingkat kepercayaan 90\% dan nilai signifikansi $(\alpha)$ 10\%. Data yang digunakan adalah data investasi infrastruktur atas realisasi anggaran pembangunan jalan dan jembatan di Dinas BMTR Provinsi Banten. Adapun model regresi yang digunakan adalah

$$
\mathrm{Y}=\alpha+\beta_{1} \mathrm{JALAN}+\beta_{2} \mathrm{JEMBATAN}+\varepsilon
$$

Keterangan:

$\begin{array}{lll}\mathrm{Y} & = & \text { Pertumbuhan ekonomi dalam } \\ & = & \text { persen } \\ \mathrm{A} & = & \text { Koefisien } \\ \mathrm{B} & = & \text { Realisasi anggaran infrastruktur } \\ \text { JALAN } & \text { jalan } \\ \text { JEMBAT } & =\text { Realisasi anggaran infrastruktur } \\ \mathrm{AN} & & \text { jembatan } \\ \mathrm{E} & = & \text { Error atau residu }\end{array}$

\section{Analisis SWOT}

Perumusan strategi untuk merumuskan strategi yang efektif untuk meningkatkan pertumbuhan ekonomi melalui investasi infrastuktur jalan dan jembatan di Provinsi Banten dengan menggunakan analisis SWOT. Analisis SWOT meliputi analisis faktor internal dan faktor eksternal, evaluasi faktor internal dan faktor eksternal (matriks IFE dan EFE), matriks internal eksternal (matriks IE) dan matriks SWOT (Rangkuti, 1997).

\section{HASIL DAN PEMBAHASAN}

\section{Hasil Analisis Anggaran dan Realisasi Infrastruktur Jalan dan Jembatan}

Berdasarkan hasil kajian APBD Dinas BMTR Provinsi Banten, diperoleh gambaran alokasi anggaran pembangunan infratruktur 
jalan dan jembatan di Provinsi Banten. Anggaran dan realisasi infrastruktur jalan dan jembatan sudah baik dengan penyerapan anggaran diatas 90\% secara berturut-turut yaitu $99.27 \%$ pada tahun 2008, 99,78\% pada tahun 2009, 99,90\% pada tahun 2010, 99,34\% pada tahun 2011 dan 93,43\% pada tahun 2012. Penyerapan anggaran yang kurang optimal terjadi pada tahun 2013 dan 2014. Pada tahun 2013 penyerapan anggaran menurun sebesar $70.64 \%$ dan $21,50 \%$ pada tahun 2014.

Penyebab rendahnya realisasi anggaran tahun 2013-2014 ada dua. Pertama, adanya lelang ulang beberapa kali atas beberapa paket pekerjaan sehingga mengakibatkan keterlambatan pelaksanaan dan realisasi anggaran. Kedua, kendala eksternal yaitu belum adanya realisasi anggaran salah satu program pembangunan jalan tahun jamak tahun 2013. Hal tersebut terkait dengan pembangunan Jalan Pahlawan
Seribu-Jalan Sepong Parung, dimana pembangunan jalan tersebut melewati lahan Puspitek. Hal yang menjadi kendala adalah pembebasan lahan Puspitek yang masih dalam proses pembebasan lahan. Proses ini melibatkan berbagai pihak yaitu Pemerintah Kota Tangerang Selatan, Pusat Penelitian Ilmu Pengetahuan dan Teknologi (PUSPITEK) Kementerian Riset Teknologi dan Pendidikan dan Kementerian Keuangan.

Proses pelimpahan lahan dari Puspitek ke Pemerintah Provinsi Banten belum selesai karena terkendala persetujuan Kementerian Keuangan. Belum disetujuinya pelimpahan lahan tersebut karena kurangnya koordinasi antar instansi terkait revisi usulan pengelolaan barang milik negara atas lahan tersebut (BPKP, 2015). Anggaran dan realisasi pembangunan jalan dan jembatan di Pemerintah Provinsi Banten selama tahun 2008 sampai dengan 2014 disajikan dalam Gambar 2.

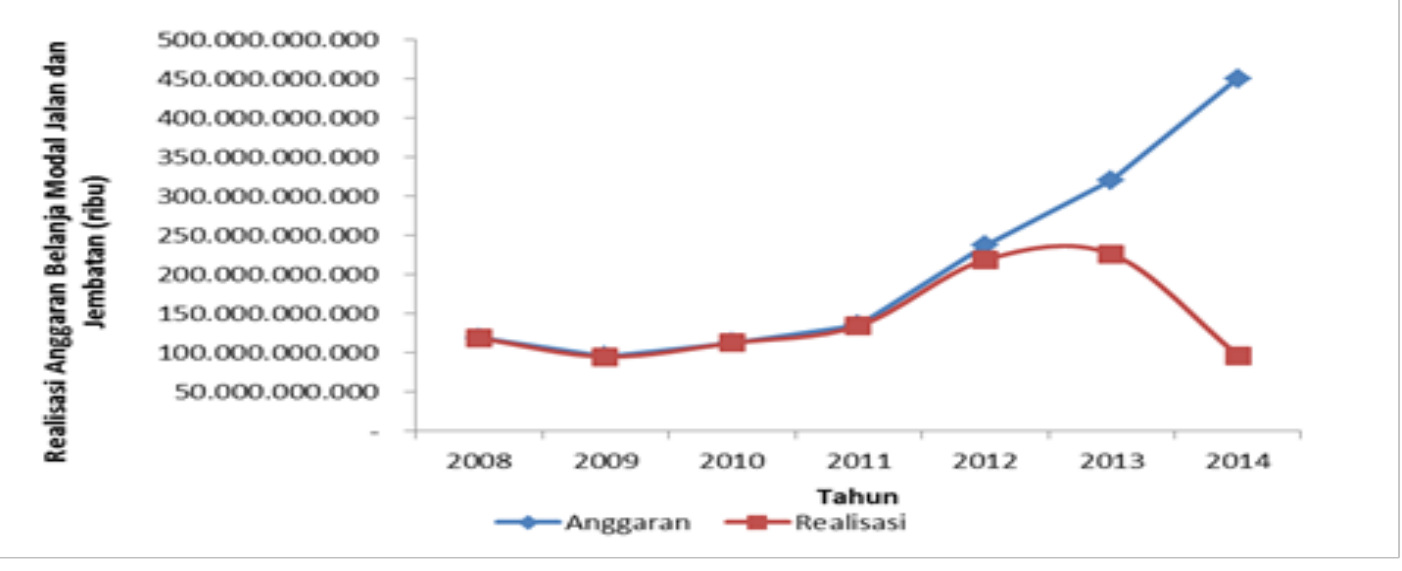

Sumber: Hasil Pengolahan Data Dinas BMTR 2008-2014

Gambar 2. Anggaran dan realisasi investasi konstruksi jalan dan jembatan

\section{Hasil Analisis Regresi Investasi Infrastruktur dan Pertumbuhan Ekonomi}

Ada empat pengujian atas variablevariabel yang digunakan sebelum dilakukan analisis regresi. Pertama, uji heretoscedasticity yang hasilnya disajikan dalam Tabel 2. Hasil uji tersebut menunjukkan bahwa tidak terdapat heteroskedastisitas data berdasarkan hasil probobilitas F statistik sebesar 0,994. Hal ini memenuhi syarat karena nilai probabilitas tersebut harus lebih besar dari 10\%.
Tabel 2. Hasil Uji Heteroskedasticity

\begin{tabular}{lrr}
\hline \hline Variable & Coefficient & Prob. \\
\hline \hline C & 0,254 & 0,936 \\
LOG(JEMBATAN) & -0.004 & 0,964 \\
LOG(JALAN) & -0.005 & 0,920 \\
\hline \hline Prob(F-statistic) & 0,9940 & \\
\hline \hline
\end{tabular}

Sumber : Hasil olahan

Kedua, uji multikolinearitas yaitu uji 61 untuk mengetahui bahwa apakah antar 
variabel independen memiliki korelasi atau tidak. Syarat tidak ada multikolinearitas adalah nilai Variance Inflation Factor (VIF) kurang dari 10. Berdasarkan hasil Tabel 3 didapatkan kesimpulan bahwa kajian ini baik dan terbebas dari multikolinearitas. Ini berdasarkan hasil uji bahwa nilai centered VIF kurang dari 10.

Tabel 3. Uji Multikolinearitas

\begin{tabular}{lc}
\hline \hline Variable & Centered VIF \\
\hline \hline LOG(JALAN) & 1,212 \\
LOG(JEMBATAN) & 1,212 \\
\hline
\end{tabular}

Sumber : Hasil olahan

Keempat, uji normalitas yang hasilnya disajikan dalam Gambar 3. Berdasarkan
Gambar 3 dapat disimpulkan bahwa kajian ini baik karena data terdistribusi secara normal. Ini berdasarkan hasil uji bahwa probabilitas sebesar 0,150 yang menunjukkan bahwa distribusi data memenuhi syarat karena sudah lebih dari $(\alpha)$ 10\%.

Ketiga, uji autokorelasi dengan uji Durbin Watson diperoleh nilai sebesar 2,018. Nilai DW tersebut berada diantara nilai DU sebesar 1,896 dan DL sebesar 3,538, dengan demikian dapat disimpulkan tidak ada autokorelasi pada model yang dihasilkan. Artinya tidak ada korelasi antara anggota serangkaian observasi yang diurutkan menurut waktu (Gujarati, 1997). Hal tersebut disajikan dalam Tabel 4.

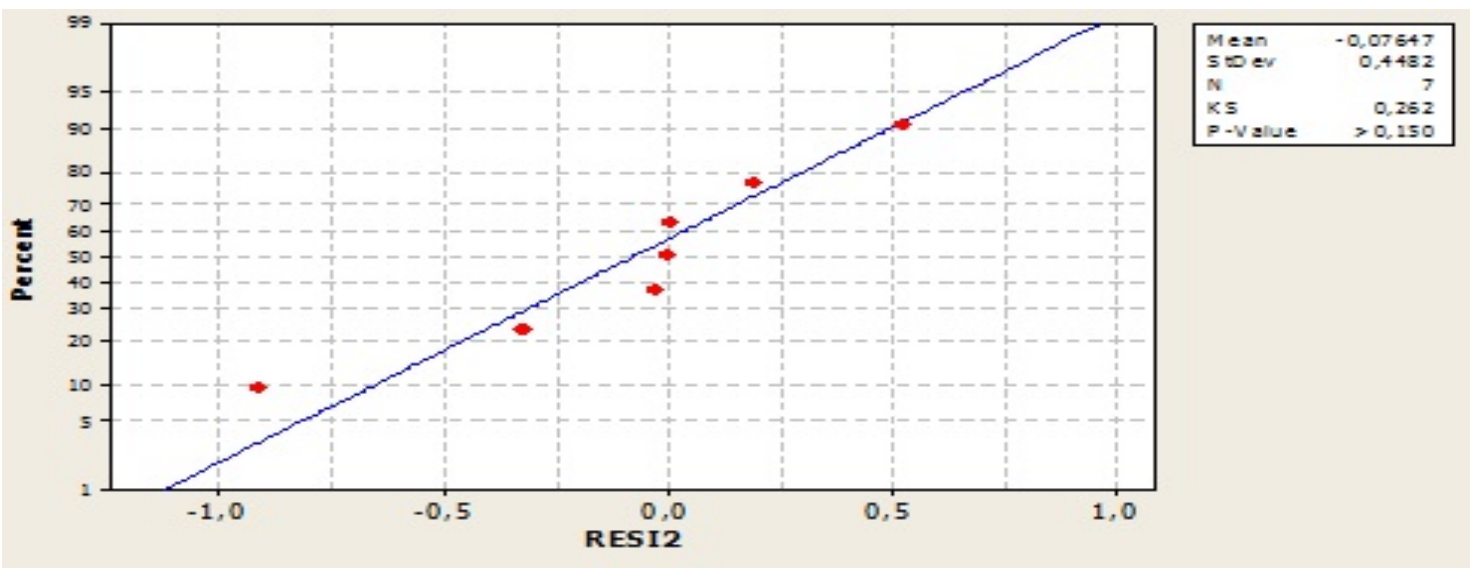

Sumber : Hasil olahan

Gambar 3 Hasil uji normalitas

Tabel 4. Hasil uji autokorelasi

\begin{tabular}{ll}
\hline Durbin-Watson Stat & 2,0182 \\
Durbin-Watson Upper (DU) & 1,8964 \\
Durbin-Watson Lower (DL) & 0,4672
\end{tabular}

Sumber: Hasil olahan

Hasil pengujian di atas menyatakan bahwa asumsi klasik terpenuhi, lalu dilakukan uji atas model regresi yang hasilnya sebagai berikut:

\section{Uji t}

Hasil perhitungan untuk variabel jalan diperoleh nilai probabilitas (signifikansi) = 0,003 . Nilai probabilitas tersebut kurang dari $\alpha 0.1(0,003<0,1)$ yang berarti dapat disimpulkan bahwa variabel pembangunan jalan berpengaruh signifikan terhadap pertumbuhan ekonomi. Selain itu, hasil perhitungan untuk variabel jembatan diperoleh nilai probabilitas (signifikansi) 0,089 . Nilai probabilitas kurang dari $\alpha 0,1$ $(0,089<0,1)$ yang berarti dapat disimpulkan bahwa variabel pembangunan jembatan berpengaruh signifikan terhadap pertumbuhan ekonomi.

\section{Uji F}

Dari hasil pengolahan data tersebut diperoleh nilai probabilitas untuk Fstatistik adalah sebesar 0,007. Nilai probabilitas tersebut lebih kecil dari $\alpha 0.1$ $(0,007<0,10)$ yang berarti dapat disimpulkan bahwa secara bersama-sama variabel jalan dan jembatan berpengaruh signifikan terhadap pertumbuhan ekonomi.

\section{Uji Koefisien Determinasi}


Berdasarkan Tabel 5 diketahui bahwa variabel bebas yaitu variabel infrastruktur konstruksi jalan dan variabel infrastruktur jembatan menunjukkan hasil yang signifikan secara statistik terhadap pertumbuhan ekonomi. Ditinjau dari nilai determinasi sebesar 87,10\% menunjukkan bahwa pertumbuhan PDRB 87.10 \% mampu ditunjukkan oleh variabel jalan dan jembatan sedangkan $12.90 \%$ dijelaskan oleh variabel lainnya .

Dari persamaan tersebut dapat diketahui bahwa setiap kenaikan realisasi anggaran pembangunan jalan $1 \%$ akan meningkatkan pertumbuhan ekonomi sebesar 0.56\%. Selain itu, Setiap kenaikan realisasi anggaran pembangunan jembatan 1\% akan meningkatkan pertumbuhan ekonomi sebesar $0,08 \%$.

Tabel 5. Hasil regresi

\begin{tabular}{lcc}
\hline \hline Variable & Coefficient & Prob. \\
\hline \hline LOG(JALAN) & 0.557 & 0.003 \\
LOG(JEMBATAN) & 0.084 & 0.089 \\
C & -6.354 & 0.027 \\
\hline \hline R-squared & 0,914 & \\
Adjusted R-squared & 0,871 & \\
Prob(F-statistic) & 0,007 & \\
\hline \hline
\end{tabular}

\section{Hasil Analisis SWOT}

Hasil analisis deskriptif menunjukkan bahwa ada beberapa faktor strategis yang mempengaruhi investasi inftrastruktur jalan dan jembatan dan berdasarkan analisis regresi mempunyai nyatanya ada korelasi positif antara investasi infrastruktur jalan dan jembatan di Provinsi Banten dengan pertumbuhan ekonomi. Faktor-faktor strategis yang berpengaruh kemudian dikelompokkan ke dalam faktor internal yang meliputi kekuatan dan kelemahan, serta faktor eksternal yang meliputi peluang dan ancaman. Adapun evaluasi faktor internal (IFE) disajikan dalam Tabel 6 .

Tabel 6 Evaluasi faktor internal (IFE)

Sumber : Hasil olahan

\begin{tabular}{|c|c|c|c|c|}
\hline No. & Kekuatan & Bobot & Rating & $\begin{array}{c}\text { Skor } \\
\text { Terbobot }\end{array}$ \\
\hline 1. & $\begin{array}{l}\text { Perencanaan partisipatif melalui musrembang } \\
\text { dalam penyusunan rencana investasi infrastruktur } \\
\text { jalan }\end{array}$ & 0,26 & 3,38 & 0,88 \\
\hline 2. & RPJMD yang sinergi dengan pemerintah pusat & 0,22 & 3,38 & 0,74 \\
\hline \multirow[t]{2}{*}{3.} & Staf yang sesuai kompetensi & 0,18 & 3,25 & 0,60 \\
\hline & Skor Variabel Kekuatan & 0,67 & & 2,22 \\
\hline No. & Kelemahan & Bobot & Rating & $\begin{array}{c}\text { Skor } \\
\text { Terbobot }\end{array}$ \\
\hline 1. & $\begin{array}{l}\text { Kebutuhan anggaran yang lebih besar daripada } \\
\text { anggaran yang tersedia pada pembangunan } \\
\text { infrastruktur jalan }\end{array}$ & 0,13 & 1,63 & 0,21 \\
\hline 2. & $\begin{array}{l}\text { Beberapa perubahan kebijakan pemerintah pusat } \\
\text { dan kementerian terkait infrastruktur }\end{array}$ & 0,11 & 1,88 & 0,21 \\
\hline 3. & $\begin{array}{l}\text { Belum diterapkanya sistem online birokrasi ( } e \text { - } \\
\text { office) internal maupun eksternal organisasi }\end{array}$ & 0,10 & 1,13 & 0,11 \\
\hline & Skor Variabel Kelemahan & 0,33 & & 0,52 \\
\hline & Total Analisis Internal & 1,00 & & 2,75 \\
\hline
\end{tabular}


Jumlah total untuk faktor internal 2,75 berarti Pemerintah Provinsi Banten memiliki kepercayaan diri yang cukup besar akan kemampuannya dalam meningkatkan investasi infrastrukturnya terhadap faktorfaktor internal. Hasil pembobotan untuk faktor internal diperoleh nilai untuk kekuatan 2,22 adalah sebesar sedangkan nilai akhir untuk kelemahan adalah sebesar 0,52.
Responden menganggap bahwa Provinsi Banten seharusnya lebih mementingkan untuk memanfaatkan kekuatan yang dimiliki dibandingkan kelemahannya.

Analisis sisi eksternal dalam menyusun strategi untuk meningkatkan pertumbuhan ekonomi melalui investasi infrastruktur jalan dan jembatan disusun dalam Tabel 7 .

Tabel 7 Evaluasi Faktor Eksternal (EFE)

\begin{tabular}{clccc}
\hline No. & \multicolumn{1}{c}{ Peluang } & Bobot & Rating & $\begin{array}{c}\text { Skor } \\
\text { Terbobot }\end{array}$ \\
\hline $\begin{array}{l}\text { Peraturan pemerintah yang lebih terbuka terhadap } \\
\text { investasi pihak swasta untuk kegiatan investasi } \\
\text { infrastruktur }\end{array}$ & 0,18 & 3,25 & 0,58 \\
$\begin{array}{l}\text { Banten sebagai provinsi penyangga dan } \\
\text { penghubung langsung dengan ibu kota merupakan } \\
\text { wilayah yang strategis untuk investasi } \\
\text { infrastruktur }\end{array}$ & 0,16 & 3,50 & 0,53 \\
3. $\begin{array}{l}\text { Belum banyak potensi wilayah di Banten yang } \\
\text { belum dimanfaatkan secara optimalnya }\end{array}$ & 0,12 & 3,63 & 0,46 \\
Kerja sama dengan pihak swasta untuk membiayai \\
pembangunan infrastruktur \\
$\begin{array}{l}\text { Adanya era perdagangan bebas ASEAN (MEA) } \\
\text { akses modal, tenaga kerja, teknologi di bidang } \\
\text { infrastruktur jalan dan jembatan semakin beragam }\end{array}$
\end{tabular}

Sumber : hasil olahan

Jumlah total untuk faktor eksternal 2,85 berarti Pemerintah Provinsi Banten mampu menghadapi perubahan yang terjadi pada lingkungan sekitar. Hasil pembobotan untuk faktor eksternal diperoleh nilai untuk peluang 2,37 adalah sebesar sedangkan nilai akhir untuk ancaman adalah sebesar 0,49. Responden menganggap bahwa Provinsi Banten seharusnya lebih mementingkan untuk memanfaatkan kesempatan yang dimiliki dibandingkan ancaman yang ada. Setelah melakukan pembobotan pada masing-masing faktor, disusunlah matriks interaksi internal dan eksternal dalam matriks IE untuk mengetahui posisi organisasi secara umum yang disajikan dalam Tabel 8. Ada beberapa hal yang perlu diperhatikan dalam menetapkan strategi pada tingkat organisasi di kuadran lima (V) Strategi mempertahankan strategi dan 
kebijakan yang ada karena sudah optimal. Pemerintah Provinsi Banten mempertahankan program pembangunan jalan dan jembatan karena memiliki korelasi positif dengan pertumbuhan ekonomi. Strategi pertumbuhan melalui diversifikasi dengan Meakukan diversifikasi anggaran investasi infrastruktur jalan dn jembatan. Misalnya melibatkan pihak swasta untuk kerja sama dan pembiayaan investasi. Hal ini dilakukan karena anggaran di bidang infrastruktur memiliki jumlah yang lebih sedikit dari kebutuhan pembangunan infrastruktur jalan dan jembatan. Dan Konsentrasi melalui integrasi horizontal dapat diaplikasikan di pemerintah daerah adalah dengan koordinasi secara intensif hal tersebut dapat berupa rapat berkala atau pembentukan tim khusus yang beranggotakan instansi-instansi terkait atas permasalahan koordinasi kegiatan investasi infrastruktur yang bermasalah.

Setelah mengetahui posisi organisasi secara umum dalam menentukan strategi dan kebijakan sesuai faktor internal dan eksternal yang dimiliki, dilakukan analisis melalui Matriks SWOT. Matriks SWOT memberikan beberapa alternatif strategi yang merupakan interaksi dari faktor Strength dan Opportnity $(S-O)$, Strength dan Weakness $(S-W)$, Threats dan Opportunity (T-O) dan Weakness dan Threats (W-T). Keempat grand strategy tersebut dijelaskan juga dalam Tabel 9.

Tabel 8. Matriks IE

\begin{tabular}{|c|c|c|c|c|}
\hline \multicolumn{5}{|c|}{ KEKUATAN INTERNAL } \\
\hline \multirow{2}{*}{} & & $\begin{array}{c}\text { Tinggi } \\
(3,0-4,0)\end{array}$ & $\begin{array}{c}\text { Rata-Rata } \\
(2,00-2,99)\end{array}$ & $\begin{array}{c}\text { Lemah } \\
(1-1,99)\end{array}$ \\
\cline { 2 - 5 } & $\begin{array}{c}\text { Tinggi } \\
(3,0-4,0)\end{array}$ & $\mathrm{I}$ & $\mathrm{II}$ & III \\
\cline { 2 - 5 } & $\begin{array}{c}\text { Sedang } \\
(2,00-2,99)\end{array}$ & IV & IE $(2,75 ; 2,85)$ & VI \\
\cline { 2 - 5 } & $\begin{array}{c}\text { Rendah } \\
(1-1,99)\end{array}$ & VII & VIII & IX \\
\hline
\end{tabular}

Sumber : Hasil olahan 
Tabel 9 Matriks SWOT

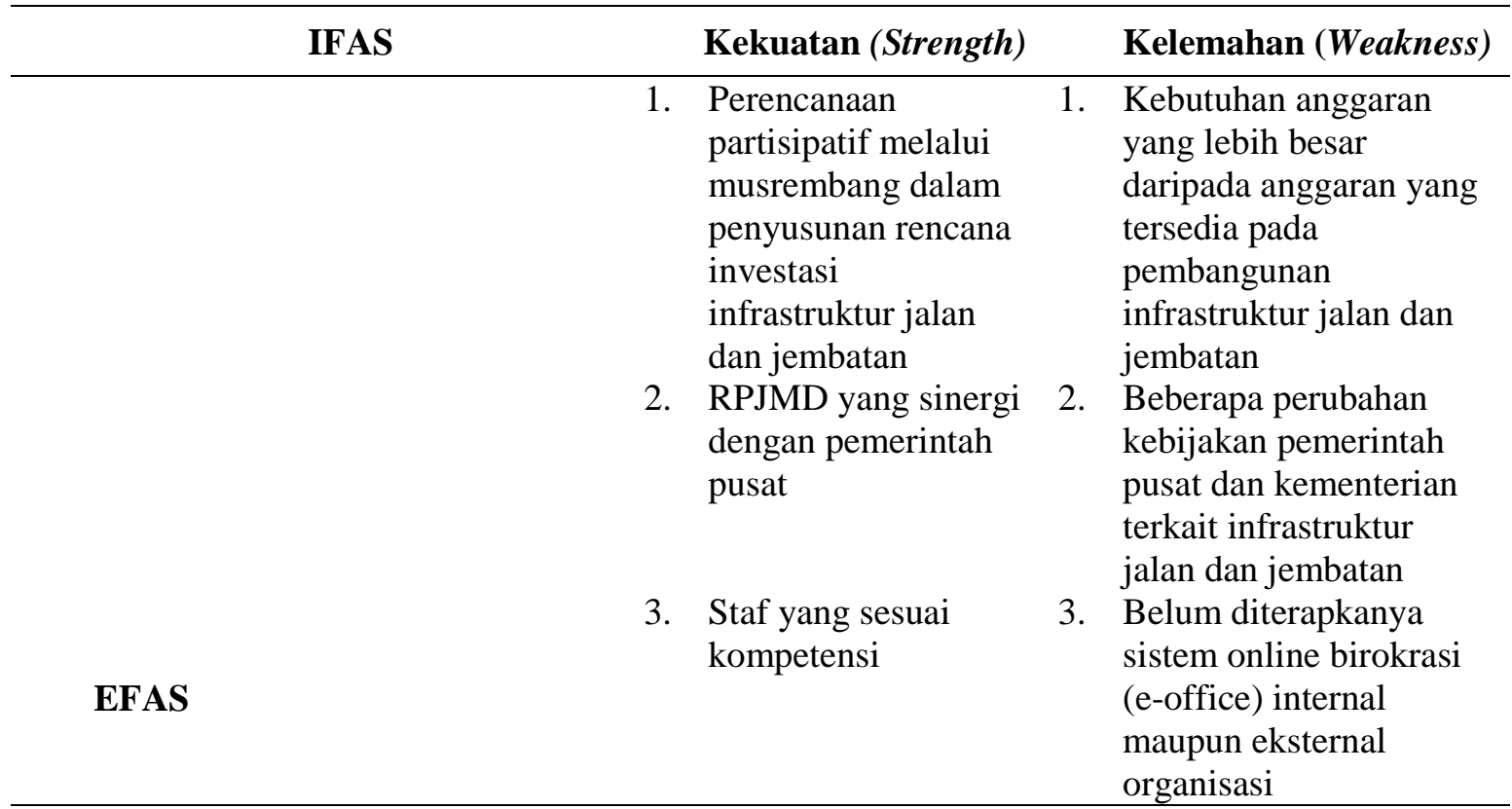

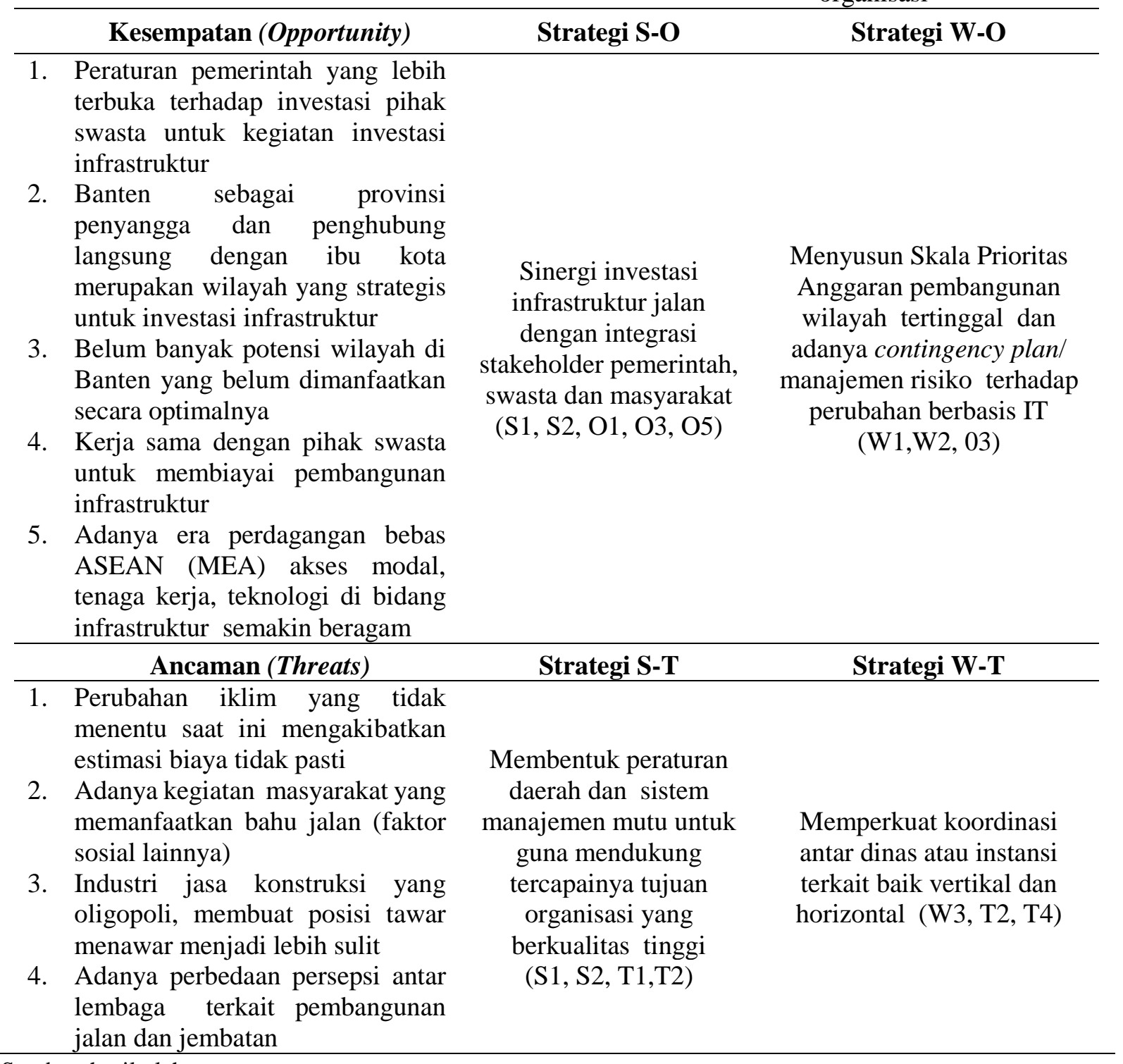

Sumber: hasil olahan 
Langkah selanjutnya adalah melakukan pembobotan terhadap hasil analisis SO, ST, WO, dan WT dan disusun prioritas strategi berdasarkan kombinasi strategi yang memiliki nilai bobot paling tinggi sampai paling rendah. Urutan alternatif strategi tersebut disajikan dalam Tabel 10.
Berdasarkan besaran bobot nilai tertinggi, maka strategi yang digunakan adalah alternatif strategi $S-O$. Strategi S-O yang perlu dilakukan adalah meningkatkan investasi infrastruktur jalan dan jembatan dengan sinergi stakeholder pemerintah, swasta dan masyarakat.

Tabel 10. Urutan alternatif Strategi SWOT

\begin{tabular}{clc}
\hline Prioritas & \multicolumn{1}{c}{ Strategi } & Bobot Nilai \\
\hline I & Strength-Opportunity (SO) & $2,22+2,37=4,59$ \\
II & Weakness-Opportunity (WO) & $0,52+2,37=2,89$ \\
III & Strength-Threats (ST) & $2,22+0,49=2,69$ \\
IV & Weakness-Threats(WT) & $0,52+0,49=1,01$ \\
\hline
\end{tabular}

sumber : hasil olahan

\section{RANCANGAN STRATEGI DAN PROGRAM}

Strategi utama yang perlu dilakukan adalah meningkatkan investasi infrastruktur jalan dan jembatan dengan sinergi stakeholder pemerintah, swasta dan masyarakat. Rancangan strategi dan program yang dapat digunakan yaitu sebagai berikut:

1. Sinergi pemerintah dan swasta

Program kerja sama Corporate Sosial Responsibility (CSR) ditujukan untuk mendorong pihak swasta ikut serta dalam pembangunan jalan dan jembatan yang ada dalam program CSR perusahaan, terutama kerjasama dengan perusahaan yang menyebabkan tingginya tingkat kerusakan jalan dan jembatan dan kemacetan misalnya pertambangan, perumahan dan perusahaan yang bergerak di kawasan industri. Hal ini juga sebagai langkah optimalisasi pembangunan jalan dan jembatan baik fungsi maupun strukturnya karena saat ini masih ada wilayah yang angka rasio jaringan jalan relatif rendah, kurangnya fasilitas jembatan di beberapa wilayah. Menurut Seeboo (2008) kerja sama antar pihak pemerintah dan swasta penting dilakukan dalam beberapa hal lain yaitu pemeliharaan, perbaikan dan membuka jalan baru. Membangun hubungan kerja sama antara pemerintah dengan pihak swasta dilakukan secara bertahap melalui penyusunan peraturan terkait mekanisme kerja sama CSR dan adanya sosialisasi terkait peraturan tersebut. Output yang diharapkan adalah peraturan daerah untuk menjadi payung hukum kegiatan yang akan dilaksanakan dan kesepakatan bersama dan melalui nota kesepahaman antara pemerintah dengan pihak swasta dapat untuk ikut serta membangun/memperbaiki jalan dan jembatan yang berhubungan langsung dengan aktivitas bisnis mereka.

2. Sinergi pemerintah dan masyarakat

Rentang kebijakan pemerintah terkait infrastukrur harus ada di tiap tingkat pemerintahan baik pusat maupun daerah, investasi di bidang infrastruktur adalah merupakan perpaduan antara kebijakan pemerintah dengan keinginan masyarakat. (Zhao et al, 2011). Pemerintah Provinsi Banten dapat bekerja sama dengan masyarakat untuk menciptakan program investasi infrastruktur yang responsif dan partisipatif. Ada dua program yang dapat diimplementasikan. Pertama, public relation on media social approach, maksud program ini adalah lebih mengefektifkan Subbagian Humas di Dinas BMTR yang bertanggungjawab untuk memberikan informasi ke masyarakat baik informasi, menjawab masukan/saran masyarakat dan menghadapi kritikan melalui media sosial misalnya twitter, facebook dan email. Pendekatan ini juga dapat digunakan 
untuk memberikan informasi rencana lelang atas paket pekerjaan yang akan dilakukan sehingga dapat lebih banyak penyedia barang dan jasa yang berkualitas dapat mengikuti proses lelang sehingga dapat mencegah terjadinya proses lelang berulang kali. Selain itu, perlu mendorong adanya kelembagaan masyarakat jasa konstruksi Provinsi Banten yang terdiri dari masyarakat umum, akademisi, penyedia barang dan jasa dan instansi lain seperti perusahaan utilitas yang terlibat dengan investasi infrastruktur jalan dan jembatan. Ini merupakan upaya peningkatan fungsi Dinas BMTR untuk melibatkan masyarakat, baik secara langsung maupun tidak langsung dalam melakukan investasi infrastruktur jalan dan jembatan sehingga dalam pelaksanaan kegiatan faktor sosial yang mengganggu pelaksanaan kegiatan dapat berkurang.

3. Sinergi antar instansi pemerintah

Sinergi antar instansi pemerintah dapat diwujudkan dengan program rapat triwulan antar untuk membahas dan menyelesaikan permasalahan yang terjadi antar instansi terkait investasi infrastruktur jalan dan jembatan dan membahas kegiatan pembangunan jalan dan jembatan yang akan dilaksanakan sehingga dapat mencegah potensi permasalahan yang timbul dan cepat dalam menangani permasalahan yang terjadi.

\section{SIMPULAN DAN SARAN}

\section{Simpulan}

1. Anggaran dan realisasi APBD Dinas BMTR Provinsi Banten menunjukkan bahwa penyerapan anggaran dan realisasi pembangunan infrastruktur jalan dan jembatan pada periode tahun 2008 sampai dengan 2012 sudah mencapai nilai diatas 90\% sedangkan tahun 2013 penyerapan anggaran menurun sebesar 70,64\% pada tahun 2013 dan 21,50\% pada tahun 2014. Penyebab rendahnya realisasi anggaran tahun 2013-2014 ada dua. Pertama, adanya lelang ulang beberapa kali atas beberapa paket pekerjaan sehingga mengakibatkan keterlambatan pelaksanaan dan realisasi anggaran. Kedua, kendala eksternal yaitu belum adanya realisasi anggaran salah satu program pembangunan jalan tahun jamak tahun 2013. Yaitu jalan Pahlawan Seribu - Jalan Sepong Parung yang melewati lahan Puspitek. Hal ini terkait belum disetujuinya pelimpahan lahan Puspitek karena kurangnya koordinasi antar instansi terkait revisi usulan pengelolaan lahan tersebut.

2. Investasi infrastruktur jalan dan jembatan signifikan berpengaruh terhadap pertumbuhan ekonomi. Pertumbuhan ekonomi 87,10\% mampu ditunjukkan oleh variabel jalan dan jembatan sedangkan 12,90\% dijelaskan oleh variabel lainnya.

3. Strategi untuk meningkatkan pertumbuhan ekonomi melalui investasi infrastruktur jalan dan jembatan di Provinsi Banten adalah sinergi stakeholder pemerintah, swasta dan masyarakat. Sinergi stakeholder pemerintah dengan swasta melalui kerja sama program CSR yang ditujukan pada pembangunan jalan dan jembatan bagi industri yang terkait dengan tingkat kerusakan jalan dan jembatan dan sebagai optimalisasi pembangunan karena saat ini masih ada wilayah yang angka rasio jaringan jalan relatif rendah dan kurangnya fasilitas jembatan di beberapa wilayah. Sinergi pemerintah dengan masyarakat adalah difungsikannya secara intensif Subbagian humas di Dinas BMTR yang memberikan informasi ke masyarakat termasuk memberikan informasi rencana lelang atas paket pekerjaan yang akan dilakukan sehingga dapat lebih banyak penyedia barang dan jasa yang berkualitas dapat mengikuti proses lelang. Sinergi antar instansi pemerintah dilakukan dengan rapat secara rutin untuk membahas dan menyelesaikan permasalahan yang terjadi antar instansi. 


\section{Saran}

1. Diharapkan, ada penelitian secara khusus dan mendalam ke daerah-daerah didalam wilayah Provinsi Banten baik kabupaten atau kota, mengenai keterkaitan anggaran pembangunan jalan dan jembatan serta realisasinya dan efektifitasnya terhadap peningkatan pertumbuhan ekonomi di daerah-daerah tersebut.

2. Meningkatkan kerja sama dan membangun komitmen dengan perusahaan yang bergerak di sektor perumahan dan pertambangan agar program CSR ditujukan untuk membangun fasilitas jalan dan jembatan yang berada dalam kawasan bisnisnya. Hal ini didasari tingkat kemacetan dan rusaknya jalan sebagai dampak dari kegiatan bisnis yang mereka lakukan.

3. Pemerintah Provinsi Banten diharapkan melaksanakan evaluasi secara berkala terhadap efektivitas pembangunan jalan dan jembatan yang telah dibangun dikaitkan dengan pertumbuhan ekonomi di wilayah sebagai acuan untuk perencanaan pembangunan jalan dan jembatan pada tahun berikutnya.

\section{DAFTAR PUSTAKA}

[Bappeda BANTEN] Badan Perencanaan dan Pembangunan Daerah Provinsi Banten. 2012. RPJMD Provinsi Banten 20122017.Banten: Bappeda BANTEN.

[Bappenas] Badan Perencanaan Pembangunan Nasional. 2015. Rencana Kerja Pemerintah Tahun 2015. Jakarta: Bappenas.

[BPKP] Badan Pengawas Keuangan dan Pembangunan. 2015. Laporan Survey Pengelolaan Infrastruktur Jalan pada Pemerintah Provinsi Banten . Jakarta : Perwakilan BPKP Provinsi Banten.

[BPS] Badan Pusat Statistik. 2015. Banten Dalam Angka 2008 sampai dengan 2014 [Internet]. [diunduh 2015 Desember 17]. Tersedia pada: http://www.bps.go.id.
[Dinas BMTR] Dinas Bina Marga dan Tata Ruang Pemerintah Provinsi Banten. 2015.

Anggaran dan Realisasi Tahun 2008 sampai dengan 2014. Banten: Dinas BMTR.

Gujarati D. 1997. .Ekonometrika Dasar. Sumarno Z, penerjemah; Gunawan $\mathrm{H}$, editor. Jakarta: Erlangga.

Janeski, Ivica, Whitacre, Brian E. 2014. Long-Term Economic Impacts of USDA Water and Sewer Infrastructure Investments in Oklahoma [Internet]. [diunduh 2015 November 28]. Journal of Agricultural and Applied. Tersedia pada:https://www.questia.com/read/1P33 332119481/Longtermeconomici mpactsofusdawaterandsewer.1/22.

Maryaningsih N, Hermanyah O, Savitri M. 2014. Pengaruh Infrastruktur Terhadap Pertumbuhan Ekonomi Indonesia. Buletin Ekonomi Moneter danPerbankan, Volume 17, Nomor 1, Juli 2014. Jakarta: Bank Indonesia.

Ma’ruf Yp, Daud J. 2014. Pengaruh Investasi Infrastruktur Jalan Terhadap Pertumbuhan Ekonomi Wilayah Di Kabupaten Pesisir Selatan Provinsi Sumatera Barat [Tesis]. Medan: Univeritas Sumatera Utara.

Prasetyo RB, Firdaus M. 2009. Jurnal Ekonomi dan Kebijakan Pembangunan 2(2):222-236. Bogor: Institut Pertanian Bogor.

Rangkuti, F. 1997. Analisis SWOT Teknik Membedah Kasus Bisnis . Jakarta: PT. Gramedia.

Seeboo A. 2008. Proposed highway asset management framework with an emphasis on economic impact analysis. Proquest Information and Learning Company UMI Number: 1453073. United States.

Sidik AP. 2011. Pengaruh Pembangunan Infrastruktur Jalan Dan Listrik Terhadap Pertumbuhan Ekonomi Di Kalimantan Tahun 1994-2008 [Tesis]. Depok : Universitas Indonesia.

Sugiyono. 2008. Metode Penelitian Kuantitatif Kualitatif dan R\&D. Bandung : Alfabeta. 
Sukirno S. 2013. Pengantar Teori

Makroekonomi. Jakarta: PT.Raja Grafindo Persada.

Supriyadi B, Muntohar A. 2007. Jembatan. Yogyakarta: CV. Beta Offset.

[UU] Pemerintah Republik Indonesia. 2004. Undang-Undang Republik Indonesia Nomor 38 Tahun 2004 Tentang Jalan.

Valeriani D. 2011. Analisis Pengaruh Kebijakan Infrastruktur Terhadap

Pendapatan Perkapita Masyarakat Kabupaten Bangka Provinsi Kepulauan Bangka Belitung [Tesis]. Bangka:Universitas Bangka Belitung. Zhao, Jerry Z, Cao, Chengxin. 2011. Funding China's Urban Infrastructure: Revenue Structure and Financing Approaches[Internet]. [diunduh 2015 November 28]. Chengxin Public Finance and Management, July 1, 2011. Tersedia pada:

https://www.questia.com/read/1P325093 66891/fundingchinasurbaninfrastructurer evenuestructure. 